\title{
Granulation of Cocoa Powder Incorporated with Green Tea Extract Using Fluid Bed Drier
}

\author{
P. Harini* \\ Food Technology, Centre for Biotechnology, Alagappa College of Technology, \\ Anna University, Chennai-600 025, India \\ *Corresponding author
}

\section{Keywords}

Fluidized bed dryer, Granulation, Green tea extract, Antioxidant, Polyphenol content

Article Info

Accepted:

07 December 2018

Available Online:

10 January 2019

\section{A B S T R A C T}

The developments of granules incorporating green tea extract with cocoa powder using fluidized bed dryer. The product is more concern to the polyphenol is abundant micronutrients in our diet, and evidence for their role in the prevention of degenerative diseases. The antioxidant properties are present more in the vegetables and fruits and as their intake are not consumed due to in conveniences and lack of time. This type of mix granules will provide sufficient intake of the antioxidant to the required amount by RDA of the daily intake of the polyphenol, major flavonoids components, and antioxidants contents. All the sources which are added to the granules are rich sources of antioxidants. To enrich this property to the product cocoa powder was selected and added. To mask of the bitterness of product two sugar components were added palm sugar and honey. The comparison was done between them and palm sugar was more acceptable according to sensory attributes. Antioxidant property and polyphenol contents were compared with the products before the designing of the lid and after designing. At each stages of the addition of components polyphenol and antioxidants was determined and compared. The result showed granules formed with the honey were much bigger when comparing to the granules formed by palm sugar. The flow rate of the liquid sample was optimized to set rpm at $2.5-3$ in the peristaltic pump with the flow rate of $0.192-0.2281 /$ hour respectively. The pressure for spraying the liquid sample was set to about $1.2 \mathrm{psi}$.

\section{Introduction}

\section{Green tea}

Tea is an infusion of the leaves of the Camellia sinensis. It is one of the most widely consumed beverages after water. Green tea is made from more mature tea leaves by withering followed by steaming or firing which inactivates the enzyme to prevent the enzymatic oxidation of catechins.

\section{Cocoa}

Cocoa exhibited the highest antioxidant activity among the samples in DPPH assays, with $836 \mathrm{mg} / \mathrm{serving}$. Their results suggest that cocoa is more beneficial to health than 
teas and red wine in terms of its higher antioxidant capacity.

\section{Honey}

Honey is a great natural source of carbohydrates which provide adequate energy. It is known that honey has also been found to keep levels of blood sugar fairly constant compared to other types of sugar. Honey's antioxidant and antibacterial properties can help improve digestive system and helps to stay healthy and fight disease.

\section{Palm sugar}

Palm sugar as one of the natural sugar sources can be obtained from most of palm trees such as coconut, aren, nipah, and siwalan.

\section{Granulation}

Granulated or agglomerated particles are more desirable than fine powders for several reasons. Improving flow properties of the mix and hence the uniformity of the dose, Increasing the bulk density of a product. Facilitating metering or volumetric dispensing, Improving product appearance, To improve flow ability and To improve dispersibility

\section{Fluid bed granulation}

Fluidization is the operation by which fine solids are transformed into a fluid like state through contact with a gas. At certain gas velocity, the fluid will support the particles giving them free mobility without entrapment.

\section{Polyphenols and antioxidants}

Polyphenols, which constitute the active substances found in many medicinal plants, modulate the activity of a wide range of enzymes and cell receptors. In this way, in addition to having antioxidant properties, polyphenol shave several other specific biological actions that are as yet poorly understood. Two aims of research are to establish evidence for the effects of polyphenol consumption on health and to identify which of the hundreds of existing polyphenols are likely to provide the greatest protection in the context of preventive nutrition. If these objectives are to be attained, it is first essential to determine the nature and distribution of these compounds in our diet.

\section{Materials and Methods}

\section{Materials for product}

Green tea extract: To $5 \mathrm{~g}$ of the dried green tea leaves $100 \mathrm{ml}$ water was added and heated up to $60 \mathrm{~min}$ in $60^{\circ} \mathrm{c}$, the crude extract was collected. About $2.5 \mathrm{~g}$ of total solid of green tea was added in $50 \mathrm{ml}$ of the extract.

Cocoa powder

Palm sugar

Honey

Soya powder

\section{Granulation using fluid bed dryer}

\section{Methodology and design}

The weighed amount of the dry samples were loaded in the glass tub enough air blow set between $30-40$ of velocity $2.48-3.48 \mathrm{~m} / \mathrm{s}$ through a bed of particle, the particle bed may assume a fluid-like state (resembling a boiling liquid). Heating the incoming air and managing air flow rate through the sample at a set temperature of $60^{\circ} \mathrm{C}$ and the inner atmospheric temperature inside the glass tub was measured with a temperature probe which was optimized $35-30^{\circ} \mathrm{C}$; the Fluid Bed Dryer provides thorough mixing and maximum 
contact of solid with moving air. The liquid samples were injected to inlet of the stainless steel lid through tubes and connect to the spraying nozzle which is made of Teflon materials. Two nozzles were designed for trails as shown in the Graph 2 and 3, the narrow nozzle shown in figure resulted in perfect spraying tool (Table 1 and 2).

Peristaltic pump was optimized at a set rpm of $2.5-3$ at a flow rate of $0.192-0.228 \mathrm{l} / \mathrm{hr}$ respectively of the liquid. For the spraying of the liquid sample air compressor was optimized to a pressure of $1.2 \mathrm{psi}$ and tubes were connecting accordingly for the spraying of the liquid sample for the granulation. The time interval was set to every $20 \mathrm{~min}$ for monitoring the fluidization process and till the granules formed different samples. The formed granules were then collected and analyzed for further studies.

\section{Analysis of antioxidant and polyphenols}

\section{DPPH radical scavenging assay}

The DPPH assay provides basic information on the antiradical activity of the health mix. The actual reaction that is taking place between the DPPH stable radical and the antioxidant $(\mathrm{AH})$ is

$\mathrm{DPPH} *+(\mathrm{AH})_{\mathrm{n}} \rightarrow \mathrm{DPPH}-\mathrm{H}+\left(\mathrm{A}^{*}\right)_{\mathrm{n}}$

Other Biochemical parameters includes, Proximate analysis, Moisture analysis, Carbohydrate analysis, Crude protein analysis (Kjeldahl method), Crude fat content (Soxhlet extraction), Total ash and Sensory evaluation were analysed and reported.

Taste, after taste, texture and overall acceptability of the health drink with addition of hot milk were evaluated. A nine point hedonic scale with $1=$ dislike extremely, $5=$ neither like nor dislike, $9=$ like extremely was used.

\section{Results and Discussion}

The formulation was more dependent on the formation of the granules. The products with honey were larger size and the colour was also dark brown, with the palm sugar the granules were more stable. The size of the granules was not fully homogenized. The time consumed for drying the product with honey was more then with palm sugar. Due to the off flavor of the soya powder the composition was reduced to one fifth and the taste was better with roasted soya. The soya was roasted at $60^{\circ} \mathrm{C}$ for $10 \mathrm{~min}$ with continuous stirring. There was loss of the yield $\%$ of the product development due to the stickiness of the binding components.

The total polyphenol content of the product developed granules were calculated and were compared at different stages of addition of the sugar components. From the graph. 2 and graph.3 the result clearly shows that the granules with addition of only sugar components (palm sugar and honey) were having lower total polyphenol content than the components with both protein and sugar components. This is due to the polyphenol content present in those components.

The antioxidant property of the products when compared with the control green tea extract was less. The product with roasted soya and palm sugar was obtained a high yield of $66.08 \%$. The lowest of all was the with soya+ palm sugar $21.15 \%$ The total polyphenol with green tea extract and other products and it was found to be that the polyphenol content was more in green tea extract $17.29 \%$ but to the next it was with a highest of other $12.68 \%$ with roasted soya + palm sugar* (Table 3-5) 
Table.1 Formulation of granulation before designing of fluid bed dryer with sugar components

\begin{tabular}{|r|l|c|c|c|c|}
\hline Sl. No. & Samples taken & $\begin{array}{l}\text { Weight of the } \\
\text { samples } \\
\text { loaded(g) }\end{array}$ & $\begin{array}{l}\text { Weight of the } \\
\text { granules after } \\
\text { drying (g) }\end{array}$ & $\begin{array}{l}\text { Size of the } \\
\text { granules } \\
\text { formed (mm) }\end{array}$ & $\begin{array}{l}\text { Time taken in } \\
\text { fluid bed } \\
\text { drying (min) }\end{array}$ \\
\hline 1. & Honey* & $\mathbf{5 0}$ & $\mathbf{1 1 9 . 5}$ & $\mathbf{4 - 1 0}$ & $\mathbf{1 8 0}$ \\
\hline $\mathbf{2 .}$ & $\begin{array}{l}\text { Palm sugar } \\
\text { ungraded * }\end{array}$ & $\mathbf{5 0}$ & $\mathbf{1 0 9 . 4}$ & $\mathbf{4 - 8}$ & $\mathbf{1 2 0}$ \\
\hline $\mathbf{3 .}$ & $\begin{array}{l}\text { Palm sugar } \\
\text { graded* }\end{array}$ & $\mathbf{5 0}$ & $\mathbf{1 0 5 . 8}$ & $4-6$ & $\mathbf{1 2 0}$ \\
\hline
\end{tabular}

$*$ Green tea extract + cocoa powder $(50 \mathrm{~g}+50 \mathrm{~g})$

Table.2 Formulation of granulation after designing of fluid bed dryer

\begin{tabular}{|r|l|c|c|c|c|}
\hline $\begin{array}{l}\text { Sl. } \\
\text { No. }\end{array}$ & Samples taken & $\begin{array}{l}\text { Weight of the } \\
\text { samples } \\
\text { loaded(g) }\end{array}$ & $\begin{array}{l}\text { Weight of the } \\
\text { granules after } \\
\text { drying (g) }\end{array}$ & $\begin{array}{l}\text { Size of the } \\
\text { granules } \\
\text { formed } \\
\text { (mm) }\end{array}$ & $\begin{array}{l}\text { Time taken in } \\
\text { fluid bed } \\
\text { drying (min) }\end{array}$ \\
\hline 1. Green tea extract +Palm & $50+30+5$ & $\mathbf{5 6 . 2 6}$ & $\mathbf{3 - 5}$ & $\mathbf{8 0}$ \\
\hline $\begin{array}{r}\text { sugar +soya powder* } \\
\text { Green tea extract +Palm } \\
\text { +roasted soya powder* }\end{array}$ & $40+30+5$ & $\mathbf{5 7 . 2}$ & $\mathbf{2 - 4}$ & $\mathbf{9 0}$ \\
\hline 3. Green tea extract +honey & $25+25+25$ & $\mathbf{7 2 . 5}$ & $\mathbf{4 - 6}$ & $\mathbf{1 0 0}$ \\
+soya powder* & & & \\
\hline
\end{tabular}

*cocoa powder $(25 \mathrm{~g})$

Table.3 Proximate analysis

\begin{tabular}{|c|c|c|c|c|c|c|c|}
\hline $\begin{array}{l}\text { Sl. } \\
\text { No }\end{array}$ & Sample & $\begin{array}{l}\text { Fat } \\
\text { content } \\
\%\end{array}$ & $\begin{array}{l}\text { Ash } \\
\text { content } \\
\text { \% }\end{array}$ & $\begin{array}{l}\text { Fiber } \\
\text { content } \\
\%\end{array}$ & $\begin{array}{l}\text { Protein } \\
\text { content } \\
\%\end{array}$ & $\begin{array}{l}\text { Carbohydrate } \\
\text { content } \%\end{array}$ & $\begin{array}{l}\text { Moisture } \\
\text { content } \\
\text { \% }\end{array}$ \\
\hline 1. & $\begin{array}{l}\text { Palm sugar }+ \\
\text { soya powder* }\end{array}$ & 6.7 & 4.25 & 3.2 & 9.2 & 76.86 & 2.91 \\
\hline 2. & $\begin{array}{l}\text { Palm sugar }+ \\
\text { roasted soya } \\
\text { powder* }\end{array}$ & 3.3 & 4.6 & 2.1 & 10.1 & 79.86 & 2.53 \\
\hline 3. & $\begin{array}{l}\text { Honey + soya } \\
\text { powder* }\end{array}$ & 8.7 & 5.8 & 3.6 & 13.2 & 68.61 & 2.70 \\
\hline
\end{tabular}

*Green tea extract + cocoa

Table.4 Colour analysis of the granules

\begin{tabular}{|c|l|c|c|c|}
\hline Sl. No. & \multicolumn{1}{|c|}{ Sample } & L $^{*}$ & A $^{*}$ & B $^{*}$ \\
\hline 1. & Palm + roasted soya* & $\mathbf{4 6 . 4 9}$ & $\mathbf{7 . 6 0}$ & $\mathbf{1 1 . 0 4}$ \\
\hline 2. & Palm + soya powder* & $\mathbf{4 6 . 3 5}$ & $\mathbf{7 . 8 2}$ & $\mathbf{1 0 . 9 7}$ \\
\hline 3. & Honey + soya powder* & $\mathbf{4 8 . 9 4}$ & $\mathbf{7 . 6 5}$ & $\mathbf{1 0 . 9 1}$ \\
\hline
\end{tabular}


*Green tea extract + cocoa powder

Table.5 Sensory analysis

\begin{tabular}{|c|l|c|}
\hline Sl. No. & \multicolumn{1}{|c|}{ Samples } & Overall acceptability \\
\hline $\mathbf{1 .}$ & Palm + soya powder* & $\mathbf{7}$ \\
\hline $\mathbf{2 .}$ & Palm + roasted soya powder* & $\mathbf{8}$ \\
\hline $\mathbf{3 .}$ & Honey + soya powder* & $\mathbf{5}$ \\
\hline $\mathbf{4 .}$ & Green tea & $\mathbf{5}$ \\
\hline $\mathbf{5 .}$ & Overall acceptance & $\mathbf{6 . 5}$ \\
\hline
\end{tabular}

*Green tea extract + cocoa powder

Graph.1 Standard graph for total polyphenol

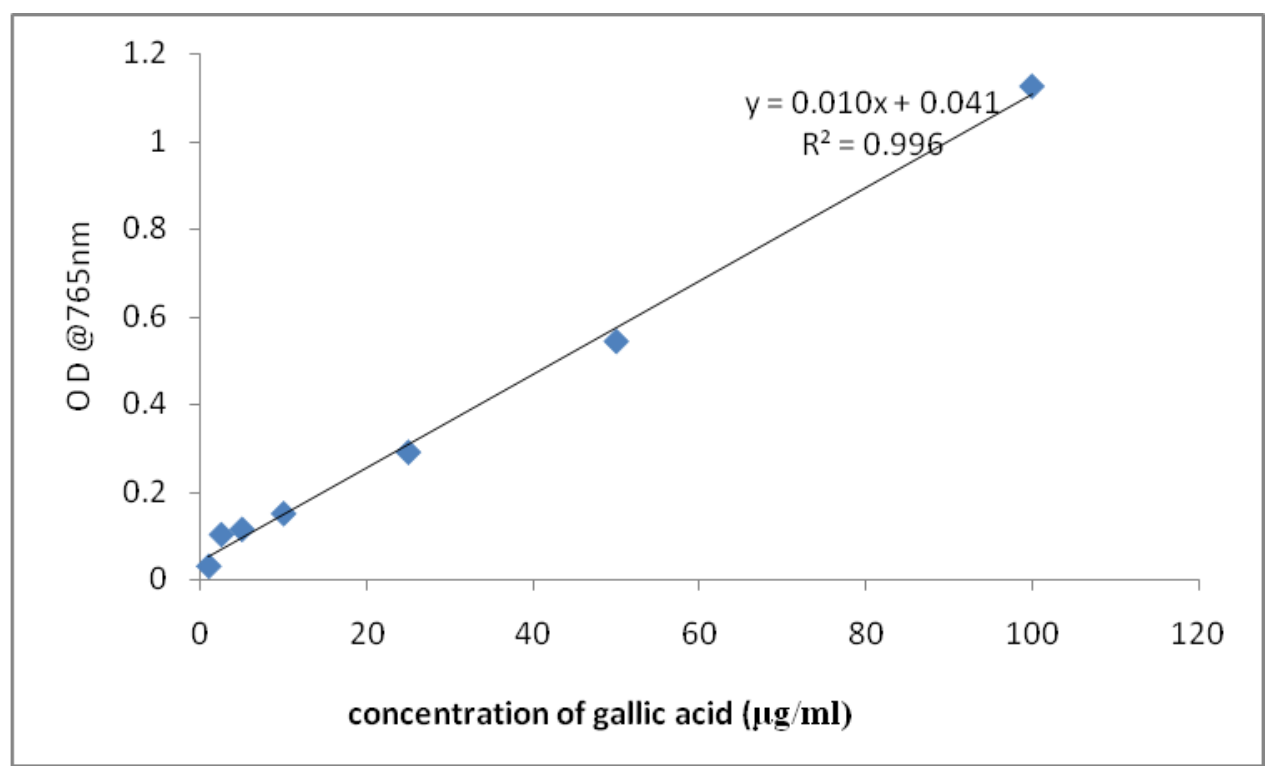

Graph.2 Total polyphenol content of granules with addition of sugar components

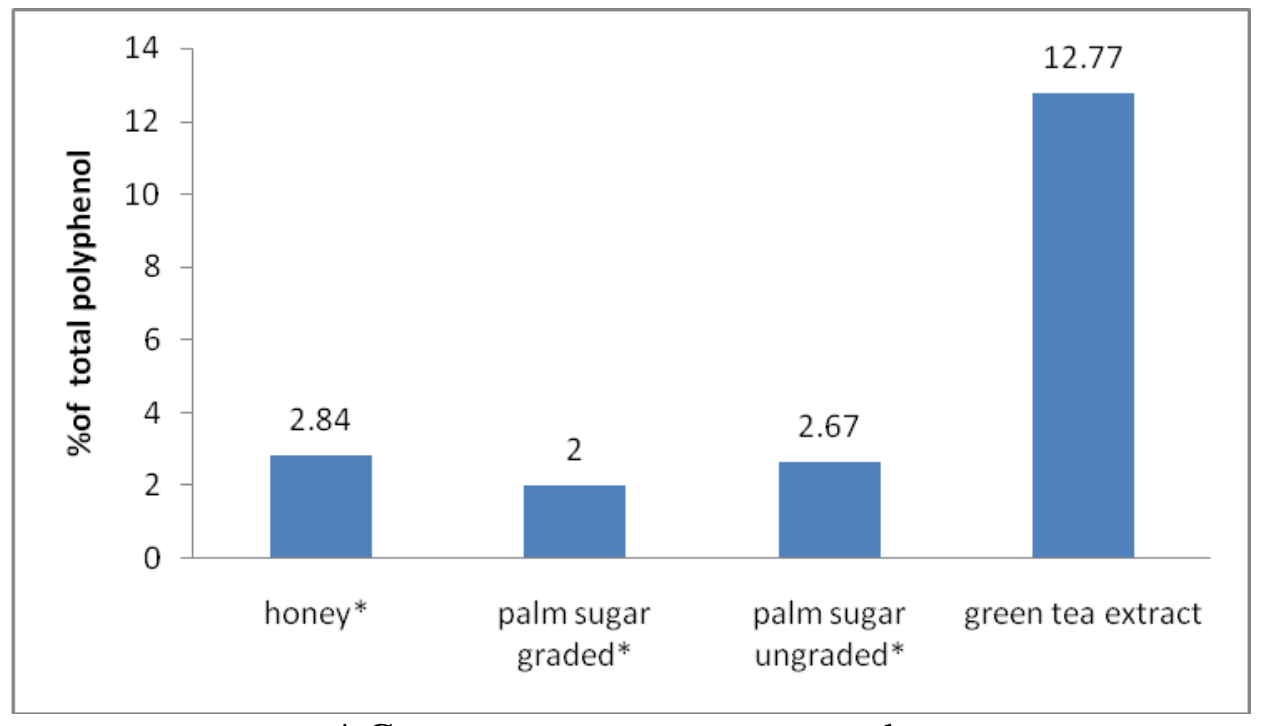

* Green tea extract + cocoa powder 
Graph.3 Antioxidant scavenging of granules with sugar component

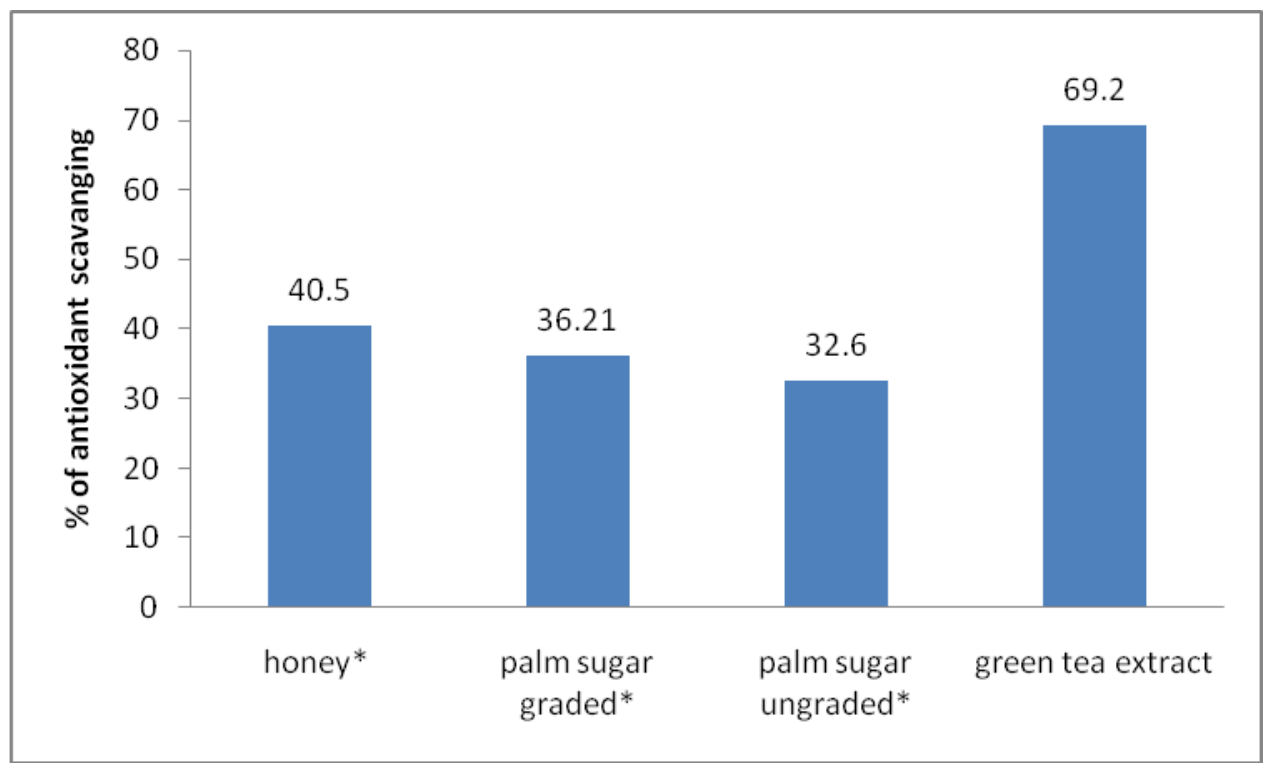

In conclusion, the study attempted to investigate the possibility of using fluid bed dryer the product was optimized for the granulation with green tea extract, cocoa powder for the enhancing the taste the sugar components honey and palm sugar introduced in and granules were formed. The comparative study was also done on the basis of the nutritional analysis of the product. For the completion of the granulation soya powder were added to the compared in the study carried.

The results were very clearly indicates that the granules formed were stable and their acceptability was also good. As per the study the granules formed between the palm and the roasted soya powder was more acceptable on the sensory basis and also with granules formation.

\section{Acknowledgement}

The author acknowledge the help provided by the Center for Food Technology, Anna University for his valuable guidance, constructive criticisms and untiring help and for utilizing the lab facilities and quality control analysis which has enabled the completion dissertation successfully.

\section{References}

Cheng QK and Chen ZM (1994) Tea and Health. Press Chinese Agri. Sci., Beijing, China. Dreosti E (2000) Antioxidant polyphenols in tea, cocoa, and wine. Nutrition. 16, 692-694.

Dept. of Biochemistry, SRM Arts and Science College, Kattankulathur, Kanchipuram, Tamilnadu, India A comparative phytochemical analysis of cocoa and green tea Indian Journal of Science and Technology Vol. 3 No. 2 (Feb 2010).

Dreosti IE (1997) Cancer biomarkers in the field of tea. Cancer Lett. 1,114.

Ki Won Lee, Young Jun Kim, Hyongjoo Lee and Chang Yong Lee (2003) Cocoa Has More Phenolic Phytochemicals and a Higher Antioxidant Capacity than Teas and Red Wine. J. Agri. Food Chem. 51, 7292-7295.

Kris-Etherton, Penny M, Keen, Carl L. Evidence that the antioxidant flavonoids in tea and cocoa are 
beneficial for cardiovascular health Current Opinion in Lipidology Articles February 2002 - Volume 13 Issue 1 - $\mathrm{p}$ 41-49

Manual of fluidized bed dryer http://www.sherwoodscientific.com/fbds/501.html

Marina Kobakhidze, Nino Seidishvili GRANULAR GREEN TEA FOODBALT 2011 Shota Rustaveli
State University, Ninoshvili str., Batumi 6010, Georgia

Singleton, V.L., Orthofer, R. and LamuelaRaventos, R.M. Analysis of total polyphenolics and other oxidation substrates and antioxidants by means of Folin-Ciocalteu reagent. In: Methods in Enzymology. Oxidants and Antioxidants, Part A, Lester Packer, ed. (1999), 299, pp. 152-178.

\section{How to cite this article:}

Harini, P. 2019. Granulation of Cocoa Powder Incorporated with Green Tea Extract Using Fluid Bed Drier. Int.J.Curr.Microbiol.App.Sci. 8(01): 556-562.

doi: https://doi.org/10.20546/ijcmas.2019.801.062 